\title{
機能的電気刺激による声帯の再運動化
}

\author{
片 田彰 博

\section{Functional Electrical Stimulation Restores Mobility of the Paralyzed Larynx}

\begin{abstract}
Akihiro Katada
The present study evaluated the clinical application of functional electrical stimulation (FES) to restore the laryngeal function in patients with vocal fold paralysis.

Canines were used in this study. We designed an electrode array consisted of 8 active platinum disk electrodes, mounted on a $10 \times 8 \times 1 \mathrm{~mm}$ silicone plate. This electrode array was placed between the thyroid cartilage and thyroarytenoid muscle. The vocal fold angle from the anterior commissure to the vocal process was measured endoscopically in the anesthetized animal. To clarify the influence of FES on reinnervation, the animals were divided into reinnervated and denervated groups. In the reinnervated group, the right recurrent laryngeal nerve was sectioned and repaired immediately. In the denervated group, the right recurrent laryngeal nerve was sectioned and not repaired.

In the reinnervated group, FES induced optimal glottal closure with a low current. The vocal fold easily adducted to the midline. Even in the denervated group, FES was able to induce vocal fold adduction. However, the induced adduction was very small, and a high current was required to move the vocal fold. The vocal fold gradually moved from the medial to the lateral side over 3 minutes of continuous stimulation, but adduction of the paralyzed vocal fold have sustained and positioned over the midline for 2 minutes.

This study showed that paralyzed adductor muscle stimulation with new shaped electrodes was able to induce optimal glottal closure. Vocal fold adduction by FES was assumed to be sufficient to improve the voice sounds in cases of unilateral vocal fold paralysis.
\end{abstract}

Keywords : vocal fold paralysis, functional electrical stimulation, vocal fold adduction, functional recovery

\section{は じめに}

喉頭は呼吸, 嚥下, 発声, 気道防御などに関与する重要 な藏器であり, その機能は適切な声帯運動によって維持さ れている. 声帯運動を制御する内喉頭筋は反回神経の支配 を受けており,この神経の障害で声帯に麻痺が生じると, 発声運動, 苝下運動, 気道防御反射運動などが障害され, 患者のQOLは著しく低下する。

反回神経自体には再生能力があるため, 障害を受けた部 分を吻合したり，欠損した部分に移植することによって内 喉頭筋に神経の再支配を誘導することができる。しかし， 反回神経は声門閉鎖筋を支配する線維と声門開大筋を支配 する線維の両方を含んでおり，それぞれの神経線維は局在 せず神経束の中を混在して走行している。 そのため, 神経 吻合や移植によって誘導される再支配は, 神経線維が本来 支配していた筋とは異なる筋を支配する過誤支配となって しまう。したがって, 筋の再支配が効率的に誘導されても, 声帯は見かけ上固定したままであり，呼吸，発声，嚥下な どに同期した合目的な声帯運動は回復しない，そして現在 の声帯麻痺に対する外科的な治療は, 固定した声带の位置
を移動させることで障害された機能の改善を期待するもの である，報告にもあるように，声帯を内転させる甲状軟骨 形成術 I 型や披裂軟骨内転術，また声帯を外転させる声門 開大術は，それぞれが十分な治療成績を挙げている ${ }^{1,2)}$. しかし, これらの治療法は声帯運動そのものを回復させて いるわけではない.

近年注目されている機能的電気刺激 (functional electrical stimulation: FES) は, 微小な電気刺激を用いて生体の障害 された機能を回復させる治療法であり, 様々な分野での臨 床応用が進んでいる，FESは感覚機能の回復を目的とした 感覚系FES と運動機能の回復を目的とした運動系FESに 大別される。感覚系FESでは重度難聴者に対する人工内耳 システムが広く普及している。運動系 FES は整形外科領域 を中心に，脳卒中や春髄損傷などの中枢性運動麻瘒患者に おける四肢の運動機能回復をめざした研究がおこなわれて いる. 我々はこの運動系FESを声带麻疩に応用し, 固定し ている声帯を再運動化するための研究を抗こなっている. 特に我々が注目しているのは, FESによる音声障害の改善 であり, 麻疩している甲状披裂筋をFESで刺激して発声に 適した声門閉鎖運動を誘発する治療法の開発をすすめてい

旭川医科大学耳鼻咽喉科・頭頸部外科学教室

Department of Otolaryngology-Head and Neck Surgery, Asahikawa Medical University 
る。この治療法を確立するためには，人工内耳の蝸牛内電 極のような体内の長期留置が安全で効率的な刺激ができる 電極と埋込型の刺激発生装置が必要であり, 我々は, 地元 の電機メーカーと共同研究を扔こなって, この目的に特化 した新しいデバイスの開発をすすめている.

\section{声門閉鎖筋刺激用電極の開発}

我々は, ネコの一側声帯麻痺モデルを用いた実験で, FESが麻痺側の声帯を内転させること，さらに誘発された 内転運動によって最長発声持続時間の延長や音声の改善が 認められることを報告した ${ }^{3)}$. しかし，これは除脳ネコを 用いた急性実験であり，甲状披裂筋の刺激にはワイヤー電 極を使用していた。ワイヤー電極は留置する位置の調節や 固定が難しく，長期間の留置には不向きである，人工内耳 電極のように, 扱いやすく, 安全に長期間留置することが 可能で, 麻痺側の甲状披裂筋を効率よく刺激することがで きるような刺激電極を開発することが急務であると考えた。

甲状軟骨形成術 I 型は一側声帯麻疩の音声改善を目的と した手術手技である，甲状軟骨の表面を露出して，仮想の 声帯の高さをマーキングし, 声帯を内方に圧排できるよう に甲状軟骨を開空して軟骨，シリコンブロック，ゴアテッ クスなどを開空部位から挿入する（図 $1 \mathrm{~A}$ )。我々はこの開 密部位から甲状披裂筋と甲状軟骨の間に板状の電極を留置 することができれば，電極と甲状披裂筋が広く接すること
A

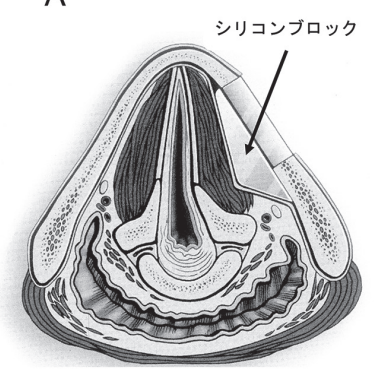

B

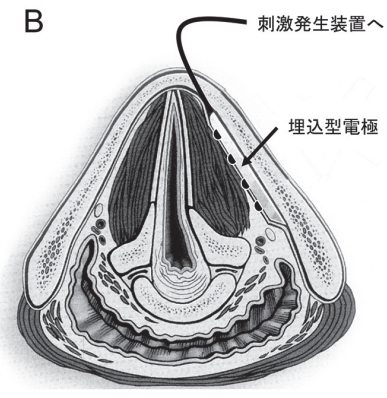

図 1 甲状披裂筋刺激用電極の模式図

A：甲状軟骨形成術 I 型に执いてシリコンブロックを挿 入した状態. B：シリコンブロックのかわりに刺激用電 極を留置した状態.
A

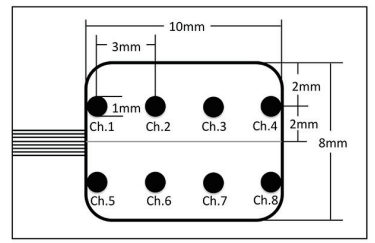

B

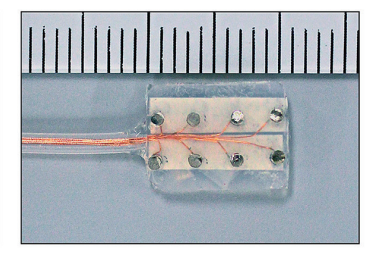

図 2 新たに開発した甲状披裂筋刺激用電極 A：設計図. B：実物の写真.
になり，効率良く刺激できるのではないかと考えた（図 1B)。 そこで, 縦 $8 \mathrm{~mm}$, 横 $10 \mathrm{~mm}$, 厚さ $1 \mathrm{~mm}$ のシリコ ンのプレートに 8 個のプラチナ電極を均等に配置するよう に刺激電極を設計した (図 2 ).

\section{刺激方法の検討}

設計した電極で麻瘏している声帯に内転運動を誘発でき るのか検証するために, イヌの一側声帯麻痺モデルを作成 した。実際の症例では声帯が固定していても, 内喉頭筋に 起こっている再支配 (過誤支配) の程度は様々であると予 想される，そこで，イヌの一側声带麻痺モデルでは反回神 経を一旦切断し直後に吻合して筋への再支配を促したモデ ル（再支配モデル）と，反回神経を切断後に断端を結紮して 吻合をしないモデル（脱神経モデル）の２種類を作成した．

右反回神経切断から 4 か月後に甲状軟骨形成術 I 型の開 空部位から右甲状披裂筋と右甲状軟骨板との間に電極を滑 り込ませるようにして留置した（図 $3 \mathrm{~A}$ )。電気刺激によっ て誘発される内転運動は口腔から挿入した硬性内視鏡を固 定して観察し, 動画を記録して解析した。保存した画像上 で仮想の正中線と声帯遊離縁上に引いた直線によって作ら れる角度を求め, 声带の位置を客観的に評価する指標とし た（図 3B)。刺激頻度は過去の検討から $40 \mathrm{~Hz}$ に固定し ${ }^{3)}$,

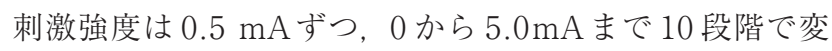
化させた。麻痺している筋を直接刺激するため, 刺激パル スの幅は通常の神経刺激よりもやや長い $0.5 \mathrm{~ms}$ と $1.0 \mathrm{~ms}$ の 2 種類で検討した。

再支配モデルで右反回神経を電気刺激すると，右甲状披 裂筋には健側と同等の誘発筋活動が観察され, 反回神経を
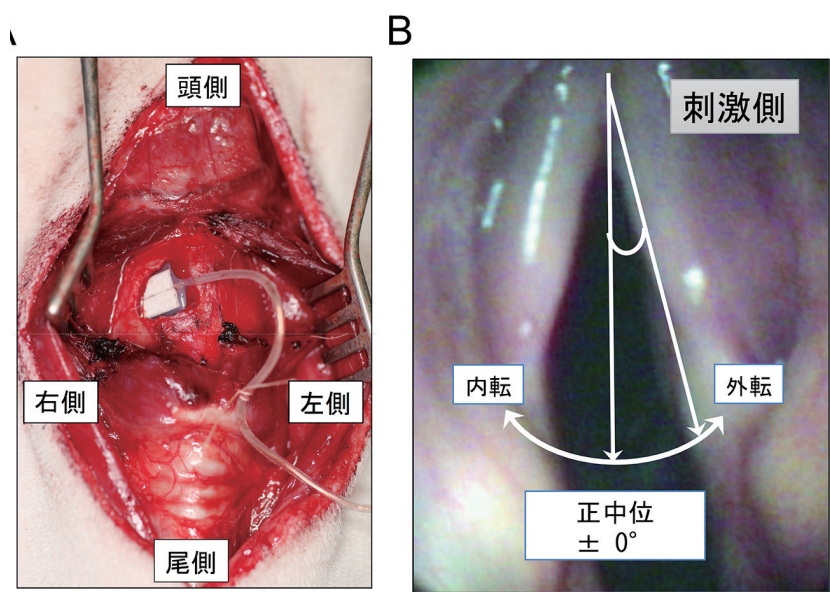

図 3 電極の留置方法と声帯運動の評価

A：右甲状軟骨翼に甲状軟骨形成術 I 型のような開空を おこなって，電極を軟骨と筋の間に挟み込むように挿入 している. B：口腔から挿入した硬性内視鏡を固定して 声帯の画像を記録する。仮想の正中線と声带遊離縁上に 引いた直線によって作られる角度を求め, 声帯の位置を 評価する. 
A

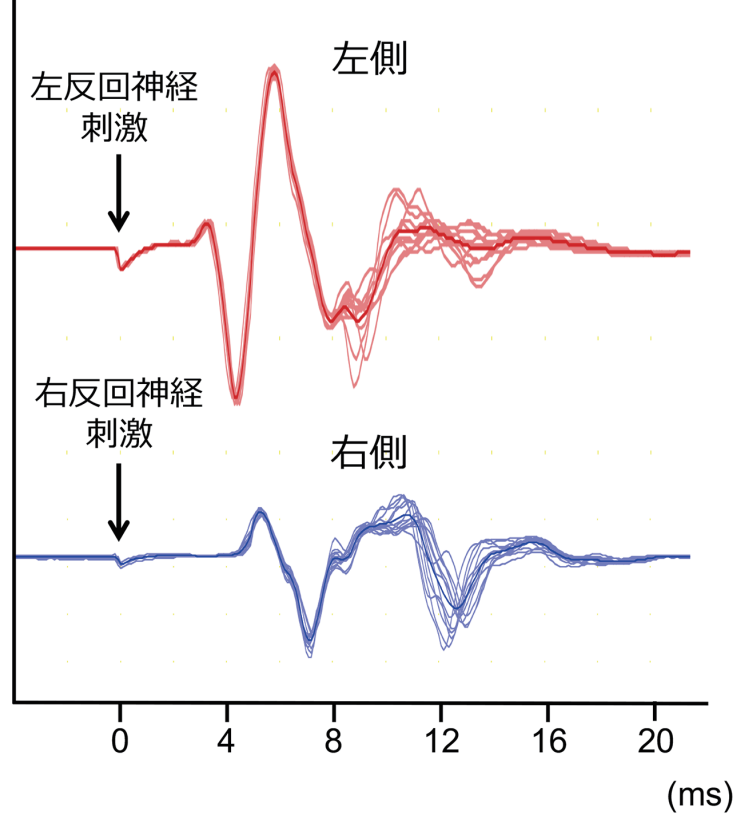

$B$

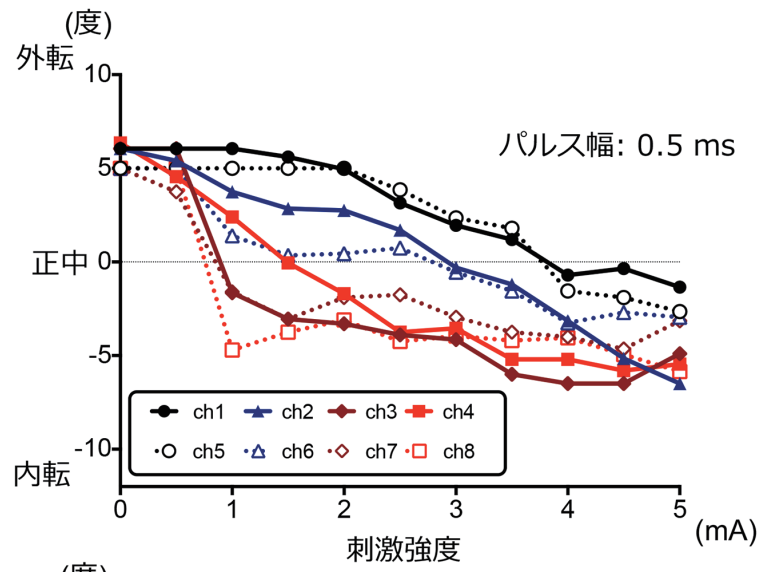

(度)

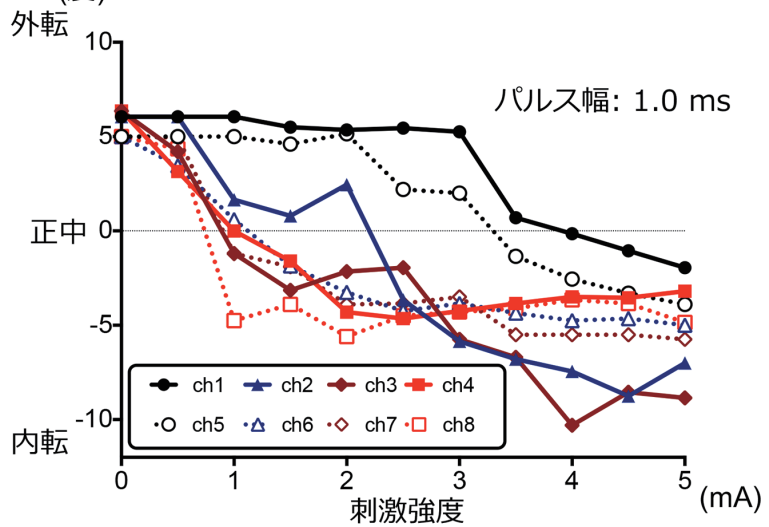

図 4 再支配モデルの結果

A：吻合した右反回神経刺激によって誘発された筋活動。再支配モデルでは反回神経刺激によって健側

と同様の筋活動が観察された. B : 各電極の刺激強度と内転の大きさとの関係.

介した甲状披裂筋の再支配が完了していることが確認され た (図 4A)。しかし，安静呼吸時の声帯運動を観察すると 右声帯は固定しており，呼吸に同期した声帯運動は観察さ れなかった。1 番から 8 番の電極でそれぞれ単極刺激をお こない，誘発された内転運動を解析した，電極の位置に よって誘発される内転の大きさには違いがあり，甲状披裂 筋の前上方に配置された電極では誘発される運動が小さ く, 後下方に配置された電極では小さい刺激強度で大きな 内転運動が誘発される傾向が認められた (図 4B)。再支配

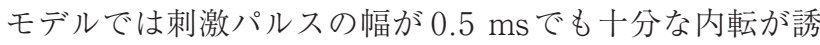
発され， $1.0 \mathrm{~ms}$ との間には違いを認めなかった。いずれの 電極でも誘発される内転の程度は刺激強度に依存して変化 していた。この結果は，内転位の調節が非常に容易である ことを示していると思われた。

一方，脱神経モデルは，再支配が起こらないように神経 吻合をしていない，再支配モデルと同様に右反回神経を刺 激したが，甲状披裂筋活動は観察されなかった（図 5A). また再支配モデルと同様に声帯は固定しており，呼吸に同 期した声帯運動は観察されなかった。 1 番から 8 番の電極
でそれぞれ単極刺激をおこない誘発される内転運動を解析 した，いずれの電極に扔いても刺激強度を上げていくと， より大きな内転運動が誘発されてはいるものの，その程度 は再支配モデルと比較すると小さい結果になっていた（図 5B)．大きな内転運動が誘発できると期待される $1.0 \mathrm{~ms} の$ パルス幅の刺激を用い， $5.0 \mathrm{~mA}$ まで刺激強度をあげても 正中を越えるような過内転を誘発することはできなかった (図 5B). 以上の結果から, 声帯が動かない過誤支配であっ ても，甲状披裂筋に再支配が起こっている方が，FESよっ て効率的に内転運動を誘発できると考えられた。

通常，筋は収縮状態が持続すると，疲労現象が生じて収 縮力が徐々に低下する。したがって，FESで強制的に声帯 を内転させても, 疲労現象によって正中位に近い状態を一 定時間以上保ことができなければ，音声改善の目的には使 用できない可能性があると考えられた，そこで，持続的な FESによって生じる筋の疲労現象を観察した，再支配モデ ルを用いて 4 番の電極に単極刺激を長時間加えたときの内 転の状態を図 6 に示す。刺激開始から約 60 秒までは正中 を越える過内転が維持されており，その後は内転が徐々に 
小さくなるものの，120秒程度までは正中位に近い内転が 持続されていた (図 6 )。健常成人の最長発声持続時間の平 均は男性で 30 秒，女性で 20 秒であることを考えると ${ }^{4)}$,

\section{A}

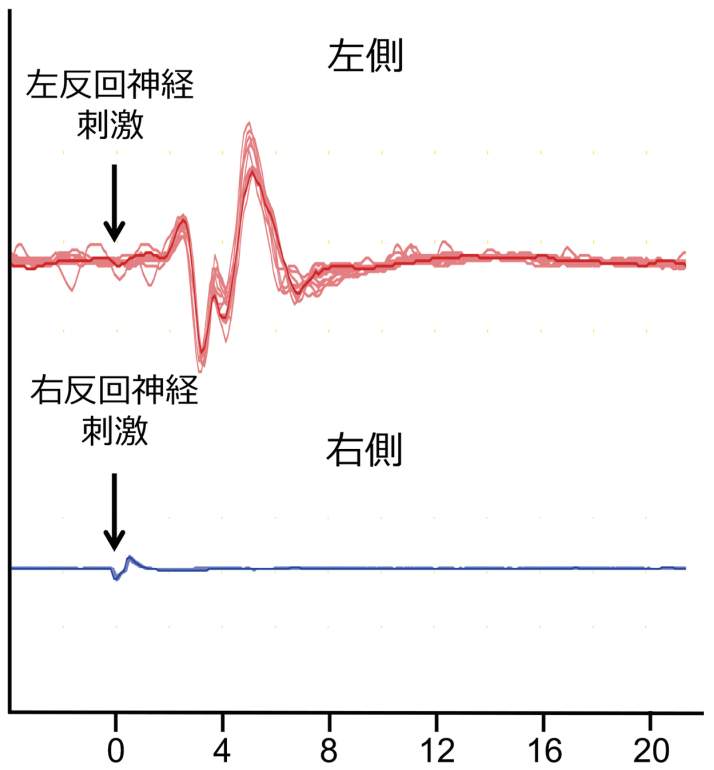

(ms)
FESにより誘発される声帯の内転は一側声帯麻痺の音声障 害の改善には十分に有効であり，筋の疲労現象は問題にな らないと推察された。

B

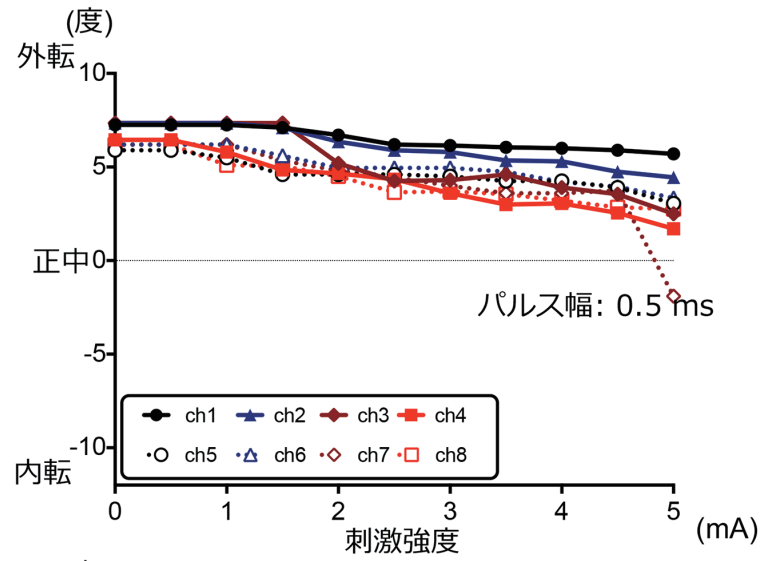

(度)

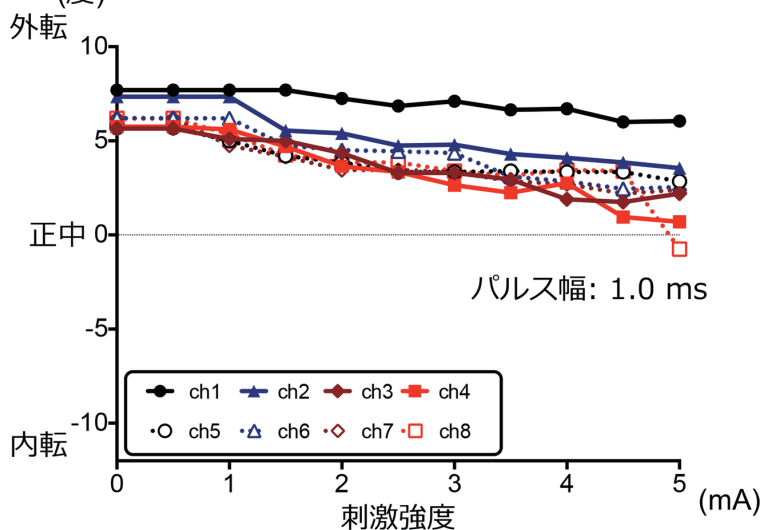

図 5 脱神経モデルの結果

A：切断した右反回神経を刺激したときの筋活動. 脱神経モデルでは反回神経を刺激しても筋活動は誘 発されない. B : 各電極の刺激強度と内転の大きさとの関係.

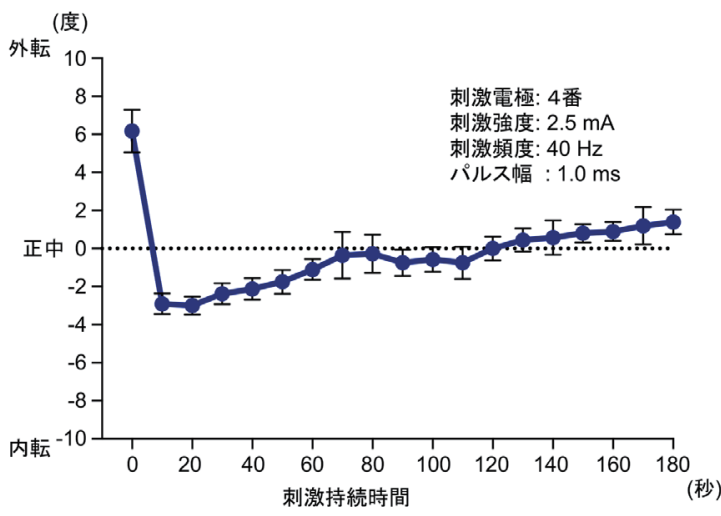

図6

図 6 麻痺側の甲状披裂筋に 180 秒間の持続刺激をおこなったときの声帯位の経時的な変化 疲労現象により時間経過とともに内転は小さくくなるが, 刺激開始から 60 秒程度は過 内転の状態が維持され，約 120 秒までは正中位が保持されていた. 


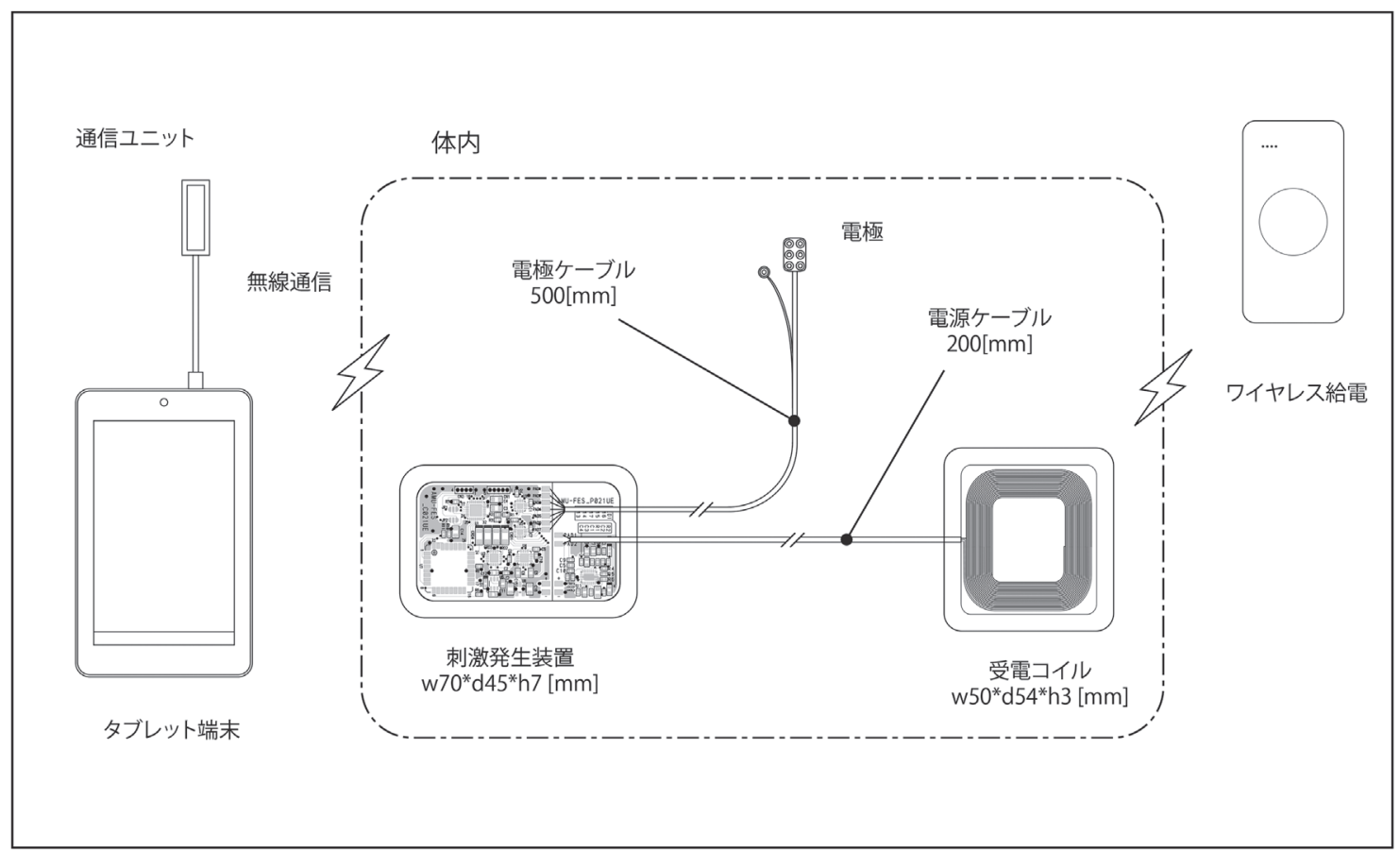

図 7 埋込型甲状披裂筋刺激装置の構成図

刺激発生装置の調節と電源供給を経皮的に体外からおこなうことができ, 体内装置は埋込可能なサイズに小型 化されている.

\section{埋込型システムの構築}

一側声帯麻疩の音声改善をめざしたFESの応用を考え た場合, 電極と刺激発生装置は体内に留置し, それらを体 外から駆動するのが理想的だと思われる．音声改善が目的 であれば，患者が会話をしないときにはシステムが休止し ていても問題がなく, 患者が音声改善を必要とするとき に，自分で容易に稼働させられることが必要になる，その 観点からも我々が理想とするシステムは心臟ペースメー カーのようなものではなく, 人工内耳のようなスタイルの ものである。すすなわち, 電源が体外にあり, 必要時に経皮 的に体内の刺激発生装置を駆動させて, 麻痺している甲状 披裂筋に刺激を送ることができるシステムである。我々は 共同研究を技こなっている電機メーカーの協力を得て, 甲 状披裂筋の刺激に特化したシステムの試作器を完成させて いる(図 7).

\section{今 後の 課 題}

これまでの研究から, 麻痺している甲状披裂筋を刺激す るための電極の理想的な形状や効率的な刺激パラメータが 解明され, その結果に基づいて, 前述の試作器が完成した。 今後はこの試作器を体内に埋め込んだ一側声帯麻疩モデル 動物を用いて, このシステムの長期間での安全性や有効性 を確認する必要があると考えている。

現システムでは，甲状披裂筋への刺激が機械的に一定の
サイクルでおこなわれるため, 健側甲状披裂筋の活動とは 同期していない．音声改善を目的とした場合には必ずしも 健側との同期が得られなくても, 効果は十分に期待でき る。しかし, 麻痺側の運動を健側と同期させることができ れば, より正常に近い声帯運動が再現できることになり， 理想的であることは言うまでもない，最近の医療機器の進 歩はめざましく，欧米では睡眠時無呼吸症候群に対する治 療として, 埋込型の舌下神経刺激装置が使われている ${ }^{5)}$. この装置は胸郭運動から呼吸をモニターして, 吸気に同期 した舌下神経の刺激を抗こなうことで, 吸気時に閉塞して いる上気道を開大させることが可能になっている，我々の システムに扒いても, 健側の甲状披裂筋や発声時に活動す る他の筋活動をトリガーにすれば, 麻痺側の声帯運動を健 側と完全に同期させることが可能になるかもしれない.

$$
\text { ま と め }
$$

FESを用いた機能改善は幅広い領域で臨床応用が進んで いる. 耳鼻咽㑨科領域では感覚系FESである人工内耳シス テムがすでに一般的な医療として確立されている。運動系 FESでは，両側声帯麻疩による呼吸障害を改善する目的 で, 声門開大筋を刺激して気道を開大し, 気管切開孔を閉 鎖する治療が臨床応用されはじめている ${ }^{6)}$. 我々が研究を 進めている一側声帯麻痺の音声改善をめざした声帯内転運 動の誘発も, 臨床応用にむけてさらなる基礎的な成績の蓄 積が必要と考えている。 
謝

辞

埋込型の甲状披裂筋刺激用システムの開発については, 共同研究者である株式会社植松電機の協力に深謝の意を表 する. また, 本研究は日本学術振興会科学研究費基盤研究

(C) No. 26462592 の交付を受けておこなった.

利益相反に該当する事項は無い.

\section{参 考 文 献}

1）片田彰博, 吉崎智貴, 太田 亮ほか：当科に扔ける甲状 軟骨形成術 I 型の検討。喉頭 $21: 12-15,2009$.

2) 佐藤克郎, 山本裕, 富田雅彦ほか：当科に招ける Ejnell 法による声門開大術施行症例の検討。日気食会 報 $60: 247-253,2009$ 。

3) Katada A, Nonaka S, Adachi M et al: Functional electrical stimulation of laryngeal adductor muscle re- stores mobility of vocal fold and improved voice sounds in cats with unilateral laryngeal paralysis. Neurosci Res 50 : 153-159, 2004.

4) 平野 滋: 音声障害評価法. 日耳鼻 $120: 752-753$, 2017.

5) Strollo PJ Jr, Soose RJ, Maurer JT et al: Upper-airway stimulation for obstructive sleep apnea. N Engl J Med 370 : 139-149, 2014.

6) Mueller AH, Hagen R, Foerster G et al: Laryngeal pacing via an implantable stimulator for the rehabilitation of subjects suffering from bilateral vocal fold paralysis: A prospective first-in-human study. Laryngoscope 126: 1810-1816, 2016.

別刷請求先 テ 078-8510 旭川市緑が丘東 2 条 1 丁目 1-1 旭川医科大学耳鼻咽喉科 ·頭頸部外科

片田彰博 